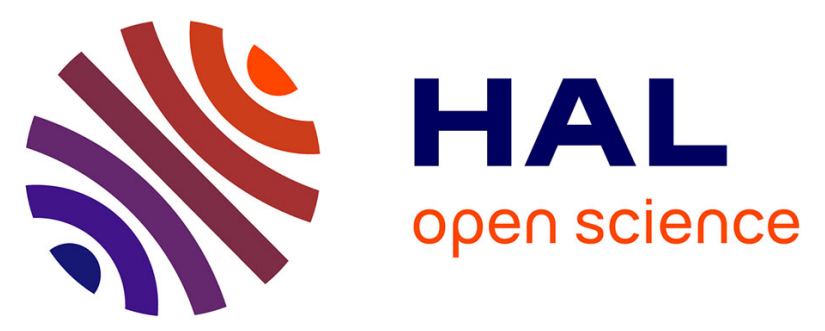

\title{
Chemical Forms of Mercury in Pyrite: Implications for Predicting Mercury Releases in Acid Mine Drainage Settings
}

\author{
Alain Manceau, Margarita Merkulova, Magdalena Murdzek, Valentina \\ Batanova, Rafal Baran, Pieter Glatzel, Binoy K Saikia, Dogan Paktunc, \\ Liliana Lefticariu
}

\section{To cite this version:}

Alain Manceau, Margarita Merkulova, Magdalena Murdzek, Valentina Batanova, Rafal Baran, et al.. Chemical Forms of Mercury in Pyrite: Implications for Predicting Mercury Releases in Acid Mine Drainage Settings. Environmental Science and Technology, 2018, 52 (18), pp.10286-10296. 10.1021/acs.est.8b02027 . hal-02314771

\section{HAL Id: hal-02314771 \\ https://hal.science/hal-02314771}

Submitted on 14 Oct 2019

HAL is a multi-disciplinary open access archive for the deposit and dissemination of scientific research documents, whether they are published or not. The documents may come from teaching and research institutions in France or abroad, or from public or private research centers.
L'archive ouverte pluridisciplinaire HAL, est destinée au dépôt et à la diffusion de documents scientifiques de niveau recherche, publiés ou non, émanant des établissements d'enseignement et de recherche français ou étrangers, des laboratoires publics ou privés. 


\section{Chemical Forms of Mercury in Pyrite: Implications for Predicting Mercury Releases in Acid Mine Drainage Settings}

Alain Manceau, ${ }^{*} \dagger$ Margarita Merkulova, ${ }^{\dagger}$ Magdalena Murdzek, ${ }^{\dagger}$ Valentina Batanova, ${ }^{\dagger}$ Rafal Baran, ${ }^{\dagger}$ Pieter Glatzel,${ }^{\ddagger}$ Binoy K. Saikia ${ }^{\S}$ Dogan Paktunc,, and Liliana Lefticariu ${ }^{\perp, \#}$

${ }^{\dagger}$ Univ Grenoble Alpes, CNRS, ISTerre, CS 40700, 38058 Grenoble, France

*European Synchrotron Radiation Facility (ESRF), 71 Rue des Martyrs, 38000 Grenoble, France

${ }^{\S}$ Polymer Petroleum and Coal Chemistry Group (MSTD), CSIR-North East Institute of Science and Technology, Jorhat-785 006, Assam, India

"Nat. Resources Canada, CanmetMINING, 555 Booth St, Ottawa, ON, K1A 0G1, Canada

${ }^{\perp}$ Southern Illinois Univ Carbondale, Dept Geol, Carbondale, IL 62901, USA

\#Southern Illinois Univ Carbondale, Environmental Resources \& Policy Program, Carbondale, IL 62901, USA

*Contact: Alain Manceau: alain.manceau@univ-grenoble-alpes.fr;

Keywords: HR-XANES spectroscopy, mercury, pyrite, marcasite, coal, Carlin-type, metacinnabar

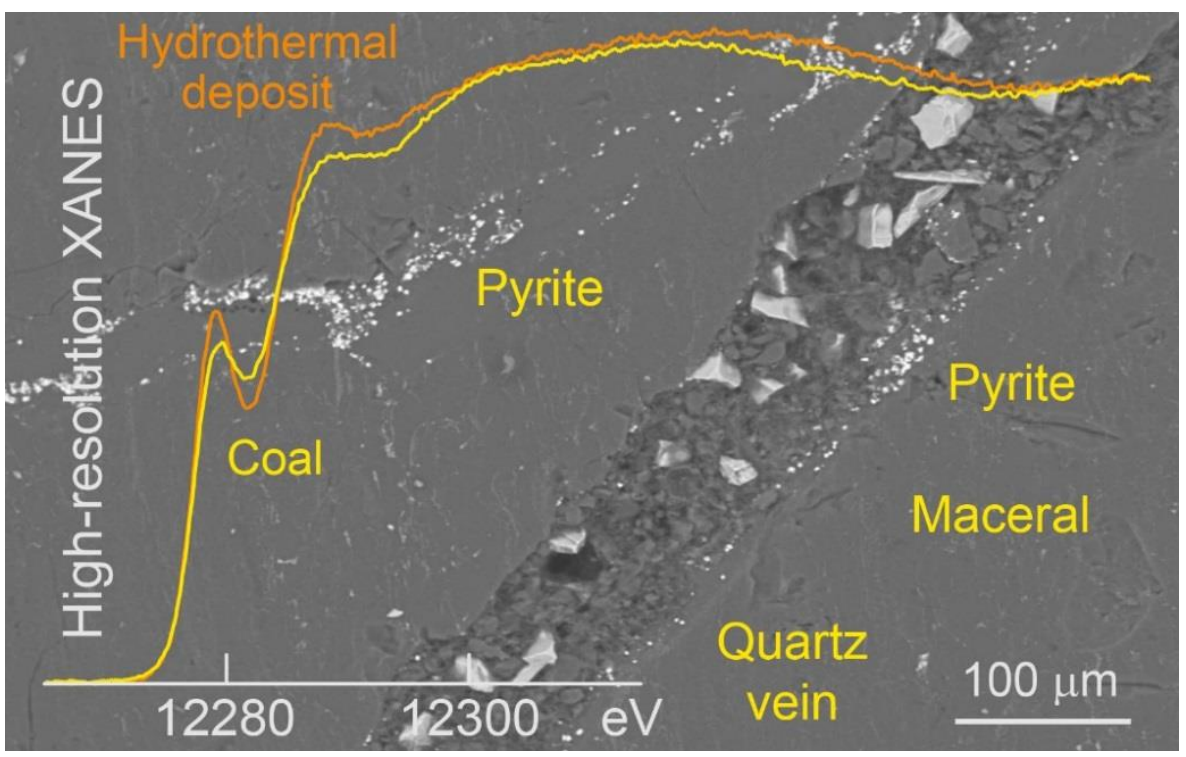

TOC 
ABSTRACT: Pyrite (cubic $\mathrm{FeS}_{2}$ ) is the most abundant metal sulfide in nature and also the main host mineral of toxic mercury $(\mathrm{Hg})$. Release of mercury in acid mine drainage resulting from the oxidative dissolution of pyrite in coal, ore and rock resulting from mining, processing, waste management, reclamation and large construction activities is an ongoing environmental challenge. The fate of mercury depends on its chemical forms at the point source, which in turn depends on how it occurs in pyrite. Here, we show that pyrite in coal, sedimentary rocks, and hydrothermal ore deposits can host varying structural forms of $\mathrm{Hg}$ which can be identified with high energy-resolution XANES spectroscopy (HR-XANES). Nominally divalent $\mathrm{Hg}$ is incorporated at the Fe site in pyrite from coal, and at a marcasite-type Fe site in pyrite from sedimentary rocks. Distinction of the two $\mathrm{Hg}$ bonding environments offers a mean to detect microscopic marcasite inclusions (orthorhombic $\mathrm{FeS}_{2}$ ) in bulk pyrite. In epigenetic pyrite from Carlintype $\mathrm{Au}$ deposit, up to $55 \pm 6 \mathrm{~mol} \%$ of the total $\mathrm{Hg}$ occurs as metacinnabar nanoparticles $\left(\beta-\mathrm{HgS} \mathrm{SP}_{\mathrm{NP}}\right)$, with the remainder being substitutional at the Fe site. Pyritic mercury from Idrija-type Hg deposit ( $\alpha$ $\mathrm{HgS}$ ore) is partly divalent and substitutional, and partly reduced into elemental form (liquid). Divalent mercury ions, mercury sulfide nanoparticles, and elemental mercury released by the oxidation of pyrite in acid mine drainage settings would have different environmental pathways. Our results could find important applications for designing control strategies of mercury released to land and water in mineimpacted watersheds.

\section{INTRODUCTION}

Mercury-bearing pyrite occurs in coal, anoxic-sulfidic sediments, sedimentary and metamorphic rocks, and in hydrothermal ore deposits. ${ }^{1-10}$ Irrespective of the type of environment, oxidative dissolution of pyrite in contact with oxygenated surface or sub-surface water releases toxic mercury to downstream ecosystems. ${ }^{11-13}$ Pyritic mercury may also be released to the atmosphere through coal combustion and sulfide ore roasting and retorting. ${ }^{14-17}$ 
Despite the widespread occurrence of pyrite in crustal rocks and its importance as the host to $\mathrm{Hg}$, little is known about the mode of incorporation of $\mathrm{Hg}$ in $\mathrm{FeS}_{2}$. This could have important implication in controlling or preventing mercury releases from mine wastes in acid mine drainage settings. Inclusion of mercury sulfide nanoparticle $\left(\mathrm{HgS}_{\mathrm{NP}}\right)$ has been imaged in hydrothermal pyrite from the Screamer Carlintype Au deposit (Nevada, USA) using electron microscopy. ${ }^{18}$ Selected area electron diffraction (SAED) was suggestive of nanocrystalline cinnabar $(\alpha-\mathrm{HgS})$. Cinnabar is the stable $\mathrm{HgS}$ polymorphic structure at ambient condition and undergoes transformation to sphalerite-type metacinnabar $(\beta-\mathrm{HgS})$ at a temperature exceeding about $315-400{ }^{\circ} \mathrm{C} .{ }^{19,}{ }^{20}$ At the estimated temperatures of $250 \pm 50{ }^{\circ} \mathrm{C}$ for the formation of Carlin-type and epithermal Au deposits, ${ }^{18} \mathrm{HgS}_{\mathrm{NP}}$ should be in the $\alpha$ - form, as suggested by Deditius et al. ${ }^{18}$. However, $\beta$-HgS can be stabilized down to ambient conditions by partial substitution of the $\mathrm{Hg}$ atoms by $3 \mathrm{~d}$ metals, such as $\mathrm{Mn}, \mathrm{Fe}$ and $\mathrm{Co}$, both in nature and in the laboratory. ${ }^{21,22}$ Furthermore, cinnabar is difficult to distinguish by electron diffraction from $\beta-\mathrm{HgS}$. The 101 and 012 reflections (3.36 $\AA$ and $2.86 \AA$ ) of $\alpha-\mathrm{HgS}$, observed in the common <211> zone axis orientation, are close in value to the 111 and 200 reflections $(3.38 \AA$ and $2.93 \AA$ ) of the $\beta$-HgS crystals in their most common $<110\rangle$ zone axis. ${ }^{23}$ Therefore, the exact mineralogical nature of $\mathrm{HgS}_{\mathrm{NP}}$ remains elusive. This information is essential for insight into the form of nanoparticulate mercury in runoff waters impacted by the oxidation of pyrite in acid mine drainage (AMD, Supporting information, SI).

In addition to being precipitated as $\mathrm{HgS}_{\mathrm{NP}}$, divalent mercury may be substituted for nominally divalent iron in the $\mathrm{FeS}_{2}$ structure. Isomorphous replacement of $\mathrm{Hg}(\mathrm{II})$ for $\mathrm{Fe}(\mathrm{II})$ in the structure of pyrite is also important because the oxidation of $\mathrm{Fe}^{2+}$ to $\mathrm{Fe}^{3+}$ and the concomitant oxidation of sulfide to sulfate sulfur in AMD settings would release free $\mathrm{Hg}^{2+}$ ions to the environment. From a steric standpoint, this substitution appears unfavorable because the ionic radius of $\mathrm{Hg}(\mathrm{II})$ (1.02 $\AA$ ) is $67 \%$ greater than that of low-spin Fe(II) (0.61 ̊). ${ }^{24}$ However, nominally monovalent $\mathrm{Au}(\mathrm{I})$ which has an ionic radius of $1.37 \AA$ can be incorporated at the Fe site of pyrite. ${ }^{25}$ Similar observation was reported by Reeder et al. ${ }^{26}$ for the 
incorporation of trace elements in calcite, and the compliance of the Ca site to substitutional impurities was attributed to the corner sharing topology of the carbonate structure. A similar rationale can be proposed for pyrite which has a framework structure consisting of $\mathrm{FeS}_{6}$ octahedra connected each to two octahedra through their apices (Figure 1a). Insertion of larger $\mathrm{Hg}$ atoms can be accommodated locally by a displacement of the nearest atomic shells (i.e., relaxation effect) and a modification of the interpolyhedral angles between the corner linked octahedra (i.e., compliance effect). The relaxation of the metal site should be extremely anisotropic, however, because $\mathrm{Hg}$ (II) has high propensity to form S$\mathrm{Hg}-\mathrm{S}$ linear coordinations. ${ }^{27,} 28 \mathrm{In} \alpha-\mathrm{HgS}, \mathrm{Hg}(\mathrm{II})$ is hexacoordinated to three perpendicular, centrosymmetric pairs of $\mathrm{S}$ atoms at $2.37 \AA$, $3.10 \AA$, and $3.29 \AA$ (Figure $1 \mathrm{~b}$ ). ${ }^{29}$ Linear geometry with two short and centrosymmetric S-Metal-S bonds is also the preferred mode of $\mathrm{Au}(\mathrm{I})$ coordination to sulfide ligands. ${ }^{25,}$ 30,31 $\mathrm{Au} \mathrm{L}$-edge EXAFS of synthetic $\mathrm{Au}(\mathrm{I})$-substituted pyrite suggests, however, a regular $\mathrm{Au}$ bonding environment with six S ligands at $2.40 \AA, 0.14 \AA$ away relative to the Fe-S distance of $2.26 \AA$ in pyrite. ${ }^{32,33} \mathrm{Hg}$ (II) can also be tetrahedrally coordinated to four $\mathrm{S}$ atoms, as in cubic $\beta$-HgS (Figure 1b). ${ }^{32}$ Four-coordination of $\mathrm{Hg}$ is in principle incompatible with the $\mathrm{FeS}_{2}$ crystal structure. If $\mathrm{Hg}$ (II) enters the $\mathrm{Fe}(\mathrm{II})$ site, its coordination should be six-fold with widely distributed $\mathrm{Hg}-\mathrm{S}$ and $\mathrm{Hg}-\mathrm{Fe}$ distances. Extreme distortion of the $\mathrm{HgS}_{6}$ bonding environment of substitutional $\mathrm{Hg}$ would hinder its characterization by standard structural techniques.

Another major challenge for speciation studies and structural characterization is the small amount of $\mathrm{Hg}$ incorporated as structurally bound species in most natural pyrite. To the best of our knowledge, no mercury concentration has been reported in pyrite from sedimentary rocks for its likely presence in trace or minor amounts. Its concentration in coal seams and bituminous coal varies considerably from the field down to the grain scale. Sub-ppm $\mathrm{Hg}$ levels $(<1 \mu \mathrm{g} \mathrm{Hg} / \mathrm{g} \mathrm{FeS}$ ), to several ppm up to a maximum of 159 ppm were reported in pyrite from coal mines of the Guizhou Province, China; ${ }^{3,}{ }^{34}$ Mercury can amount to several ppm in Herrin and Springfield coal, Illinois; ${ }^{35}$ and reach 20 ppm in Donbas coal, Ukraine; ${ }^{36}$ 
Point analyses of single pyrite grains from Alabama and Kentucky coal by micro-PIXE and laser-ablation ICP-MS analysis indicated mercury concentrations up to several tens of ppm. ${ }^{6,37}$ Even larger compositional variability is observed in hydrothermal pyrite from metal sulfide deposits (e.g., $\mathrm{Cu}, \mathrm{Au}$, $\mathrm{Tl}$ ), ranging from less than $1 \mathrm{ppm}$ to several hundreds and thousands ppm. ${ }^{5,18,38,39}$ Hydrothermal pyrites with record concentrations of $\mathrm{Hg}$ are not of interest here because the metal is either dominantly precipitated as mineral nanoparticles or dominantly present in elemental form $\left(\mathrm{Hg}_{1}^{0}\right) .{ }^{40} \mathrm{Only}$ a minor fraction of total $\mathrm{Hg}$ is incorporated into the pyrite structure at the atomic scale. The samples chosen for this study cover the variety of natural occurrences with $\mathrm{Hg}$ concentrations ranging from 0.3 ppm to 60.9 ppm, with the exception of one pyrite outlier at $7.41 \mathrm{wt} \%$ from the Idrija $\mathrm{Hg}$ mine (Table 1). The sample series was complemented by a sedimentary marcasite (orthorhombic $\mathrm{FeS}_{2}$ ) containing $6.0 \mathrm{ppm} \mathrm{Hg}$ because pyrite crystals sometimes contain microscopic intergrowth of marcasite layers. ${ }^{41,42}$

EXAFS spectroscopy is the prime structural method for exploring the crystal chemistry of trace and minor elements. To date, the weight sensitivity of quality $\mathrm{Hg} \mathrm{L}_{3}$-edge EXAFS is at best 5-10 ppm in a low $\mathrm{Z}$ matrix. ${ }^{43}{ }^{44}$ It is unknown in $\mathrm{FeS}_{2}$ matrix, but predicted to be a few hundred ppm based on absorption calculation, well above the desired sensitivity to measure small amounts of substitutional $\mathrm{Hg}$ in pyrite. Compared to EXAFS, XANES spectroscopy has a detection limit of about five to ten times lower. In addition, XANES can provide geometric information, and it is less sensitive to structural disorder around the photoabsorbing atom. ${ }^{45-49}$ Therefore, XANES allows, in theory, more precise identification of the varying mixtures of $\mathrm{Hg}(\mathrm{II})$ species in $\mathrm{FeS}_{2}$.

However, XANES suffers from poor spectral resolution at the L edge of $5 \mathrm{~d}$ elements (Figure $2 \mathrm{a}$ ). ${ }^{50}$ Resolution is limited by the short lifetime of the core-hole which follows the photoelectric effect and which lifespan decreases when the atomic number increases. With a width of $5.8 \mathrm{eV}$ at the $\mathrm{L}_{3}$ edge of $\mathrm{Hg},{ }^{51}$ the $2 \mathrm{p}_{3 / 2}$ core level obliterates all XANES features normally used to characterize the bonding environment of the photoabsorber (Figure 2a). Here, the fine structures in the absorption edge were 
unraveled by measuring the $\mathrm{L}_{\alpha 1}$ fluorescence line $\left(3 \mathrm{~d}_{5 / 2} \rightarrow 2 \mathrm{p}_{3 / 2}\right.$ transition) with a spectrometer based on Bragg optics. ${ }^{52}$ The spectral features are sharper because the intrinsic broadening is now determined by the width of the $3 \mathrm{~d}_{5 / 2}$ emission line, which is $2.0 \mathrm{eV}$ for $\mathrm{Hg} .{ }^{51}$ Elemental sensitivity is also enhanced because background photons from elastic scattering at the excitation energy and from the intense Fe K $\alpha$ fluorescence line are filtered by the analyzer crystals of the spectrometer. In such conditions, the signalto-noise ratio only depends on the counting statistics, therefore the total counting time. The drawback of high energy-resolution XANES (HR-XANES) spectroscopy, however, is the low efficiency of standard X-ray spectrometers because the sample and analyzer, both mounted on a Rowland circle, are $1 \mathrm{~m}$ apart. We used for this study a new $0.5 \mathrm{~m}$ spectrometer, ${ }^{53}$ employed previously to study the chemical form of mercury in biologic samples down to a concentration of 0.5 ppm Hg. ${ }^{54,55}$

\section{MATERIALS AND METHODS}

Samples are identified by a letter-number scheme where the letter indicates the geological setting (Coal, Sedimentary, Hydrothermal) and the number signifies the total Hg concentrations in ppm (Table 1). Two coals were studied, one from the Herrin $n^{\circ} 6$ seam in the Illinois Basin, USA, and another from the Bapung coalfield of Meghalaya, northeast India (Figure 3 and Figures S1-S4). The two bulk coals contained $0.13 \mathrm{ppm} \mathrm{Hg}$ (Herrin) and $0.22 \mathrm{ppm} \mathrm{Hg}$ (Meghalaya) only. The contrast between the high density of pyrite $\left(\sim 4.9 \mathrm{~g} / \mathrm{cm}^{3}\right)$ and the low density of the maceral matrix being suitable for gravity concentration of pyrite grains, heavy and light concentrates were separated on a shaking table. The heavy isolates had 48.6 ppm (C-49, Herrin) $\mathrm{Hg}$ and $182.3 \mathrm{ppm}$ (C-182, Meghalaya), and the light isolates had $0.3 \mathrm{ppm}(\mathrm{C}-0.3$, Herrin) and $2.5 \mathrm{ppm}(\mathrm{C}-2$, Meghalaya) $\mathrm{Hg}$ (Table 1). The isolated light fractions had more $\mathrm{Hg}$ than the bulk because clay particles, which contain little $\mathrm{Hg}$, were removed in the wash water. The heavy isolates are not pure pyrite because the coals contain monazite, sillimanite $\left(\sim 3.2 \mathrm{~g} / \mathrm{cm}^{3}\right)$, anatase/rutile $\left(\sim 4 \mathrm{~g} / \mathrm{cm}^{3}\right)$ and zircon $\left(\sim 4.6 \mathrm{~g} / \mathrm{cm}^{3}\right)$, among other ancillary minerals (Figure $3 \mathrm{~d}$ and Figure 
S4). Hg was detected only in pyrite by electron probe microanalysis (EPMA) with a beam diameter of 3$5 \mu \mathrm{m}$ and a detection limit of $54 \mathrm{ppm}(\mathrm{SI}) . \mathrm{Hg}$ contents were extremely heterogeneous from grain to grain or assemblages of grains in case of framboidal pyrite. They ranged from below 54 ppm to maximum values of $79 \mathrm{ppm}(n=14)$ for C-49 framboidal pyrite (Figure $3 \mathrm{~b}$ and Figure S2), $89 \mathrm{ppm}(n=39)$ for C49 massive pyrite (Figure 3c), and $103 \mathrm{ppm}(n=80)$ for C-182 pyrite (Figure 3e, Figure S4 and Table S1). Point concentrations measured on C-49 are consistent with the bulk analysis of 48.6 ppm measured on the heavy fraction enriched in pyrite. Point concentrations for C-182 were all lower than the bulk value of $182.3 \mathrm{ppm}$, which we attribute to the compositional variability of the pyrite grains as a function of their size. Pyrite is associated with quartz veins in Meghalaya coal and has a grain size between one and four micrometers (Figures 3d and 3e). Heating and melting of the embedding epoxy at high acceleration voltage and electron current prevented their analysis by EPMA and only the fewer bigger grains could be analyzed (Figure S4). Small pyrite crystals likely contain more $\mathrm{Hg}$ than the large crystals analyzed by EPMA.

Four Carlin-type samples were studied, three from the Goldstrike Au deposit in Nevada, USA (H-17, H-24, H-60), and one from Park City Au deposit in Utah, USA (H-2). The Park City sample is a single pyrite crystal, whereas the Goldstrike samples are roaster feed powders. The mineralogy is dominated by quartz (45-62\%), muscovite (11-16\%), and calcite/dolomite (10-22\%); pyrite amounts to $2 \%$. Based on a total of 27 EPMA analyses from 16 pyrite grains, $\mathrm{Hg}$ concentrations in $\mathrm{H}-24$ and $\mathrm{H}-60$ range from the minimum detection limit of $78 \mathrm{ppm}$ to $670 \mathrm{ppm}$ (Figures S5 and S6 and Tables S3 and S4). This range coincides with that measured by EPMA on pyrite grains from Deep Star Au deposit. ${ }^{5}$ Besides pyrite, $\mathrm{Hg}$ was detected in one arsenopyrite grain, not in other sulfide minerals $(230 \mathrm{ppm})$. Pictures of the pyrite and marcasite crystals, additional optical and electron images, EPMA results and details of sample preparation are given in the SI. 
The Hg L 3 -edge HR-XANES spectra were measured at 10-15 K on beamline ID26 of the European Synchrotron Radiation Facility (ESRF). Detailed information on data acquisition and analysis is given in the SI. The pyrite spectra were compared to a spectral database of mercury sulfide and thiolate references described previously. ${ }^{23}$ To better support the data analysis, and in particular substantiate some of the fine spectral features, and also facilitate further studies, all data are provided in the SI.

\section{RESULTS AND DISCUSSION}

Bonding and coordination fingerprint. Comparison of $\mathrm{HR}-\mathrm{XANES}$ spectra for $\mathrm{Hg}$ coordinated to sulfide or thiolate $\left(\mathrm{SR}^{-}\right)$ligands with known geometry identifies three "indicator" regions denoted A, B, and C (Figure 2). Region A, situated in the rising part of the main edge, has spectral features resulting from transitions of the $2 \mathrm{p}_{3 / 2} \mathrm{Hg}$ photoelectron to hybridized $6 \mathrm{~s} / 5 \mathrm{~d} \mathrm{Hg}-3 \mathrm{~s} 3 \mathrm{p} \mathrm{S}$ bound-states. ${ }^{56}$ This region is therefore sensitive to the nature, number and conformation of the mercury ligands. Linear coordination gives rise to an intense transition in the near-edge, which decreases in intensity when the S-Hg-S angle deviates from linearity. Typically, S-Hg-S bending occurs when a second shell of ligands approaches $\mathrm{Hg}$ perpendicularly to the $\mathrm{S}-\mathrm{Hg}-\mathrm{S}$ direction, as in the $2+4$ coordination of $\alpha-\mathrm{HgS}$ (Figures $1 \mathrm{~b}$ and $2 \mathrm{~b}$ ). The $\mathrm{S}-\mathrm{Hg}-\mathrm{S}$ angle is smaller when the secondary ligand distance is shorter. A similar relationship exists between the RS-Hg-SR angle and length of the opposite $\mathrm{Hg}-\mathrm{S}$ bond in $\mathrm{Hg}(\mathrm{SR})_{3}$ complex ${ }^{27}$. In fourcoordinate $\beta-\mathrm{HgS}$, which has a S-Hg-S angle of $109.4^{\circ}$ (Oh symmetry), the preeminent near-edge peak of two-coordinate $\mathrm{Hg}$ is replaced by a shoulder (Figure $2 \mathrm{c}$ ).

Region B extends from about $10 \mathrm{eV}$ below the edge maximum to about $20 \mathrm{eV}$ above. In this energy range, the photoelectron has a small kinetic energy, thus a high mean free path, meaning that it has a high probability of being scattered multiple times by heavy atoms surrounding the photoabsorbing $\mathrm{Hg}$ atom. Modulations of the absorption signal by $\mathrm{Hg}$ neighbors are clearly seen on the $\alpha-\mathrm{HgS}$ and $\beta-\mathrm{HgS} \mathrm{HR}-$ XANES spectra measured at 10-15 K (Figures $2 \mathrm{~b}$ and $2 \mathrm{c}$ ). The multiple-scattering events have a much 
lower probability in disordered $\beta-\mathrm{HgS}_{\mathrm{NP}}$, but are still observed with regard to the mononuclear, fourcoordinate $\mathrm{Hg}(\text { Cysteine })_{4}$ complex which has a featureless bell-shape top edge (Figure $2 \mathrm{~d}$ ).

Region C follows region B and corresponds to the first EXAFS-like oscillation. The energy of the post-edge absorption depends on the distance between the photoabsorbing $\mathrm{Hg}$ atom and the ligand shell. ${ }^{57}$ A shift to lower energy signifies longer $\mathrm{Hg}$-ligand distances, and is observed typically when $\mathrm{Hg}$ is tetrahedrally coordinated to sulfur atoms (Figure 2e). The three HR-XANES fingerprints are used below to determine the coordination and local structure of $\mathrm{Hg}$ in pyrite.

Bonding environment of $\mathbf{H g}$ in pyrite from coal. The HR-XANES spectra from the four coal samples are statistically identical, which suggests that there is only one single form of $\mathrm{Hg}$ in pyrite (Figure S9). The four spectra were averaged to obtain one spectrum representing coal pyrite (spectrum "Coal"), and the average spectrum analyzed against mercury minerals $\left(\alpha / \beta-\mathrm{HgS}, \beta-\mathrm{HgS}_{\mathrm{NP}}, \mathrm{HgSe}\right)$ and $\mathrm{Hg}(\mathrm{II})$ complexed on natural organic matter (Hg-NOM). The coal spectrum did not match either spectrum of the model compounds or a weighted sum of them. Region A has a near-edge peak of lower intensity than the two-coordinate $\mathrm{Hg}(\mathrm{SR})_{2}$ reference and region $\mathrm{C}$ is shifted to lower energy (Figure 4a). Regions A and $\mathrm{C}$ distinguish a $2+k$ coordination. Region $\mathrm{B}$ has a bell-shape, indicating that the $\mathrm{Hg}$ atoms are not clustered locally (i.e., no $\mathrm{Hg}-\mathrm{Hg}$ pairs). A clue to the bonding site and local environment of $\mathrm{Hg}$ in coal pyrite is provided by a comparison with the $2+4 \mathrm{Hg}$ coordination of $\alpha-\mathrm{HgS}$ (Figures $1 \mathrm{~b}$ and $4 \mathrm{~b}$ ). The coal and $\alpha-\mathrm{HgS}$ spectra have the same A and C signatures, but region B has a distinguishing feature. We interpret this result to indicate that $\mathrm{Hg}$ (II) replaces $\mathrm{Fe}(\mathrm{II})$ in pyrite with a $2+4$ coordination and is not segregated locally. Although the incorporation of $\mathrm{Hg}$ leads to a departure of the cubic point group at the substitutional Fe site, the distortion may be local and not lead to a wide distribution of the $\mathrm{Hg}-\mathrm{Fe}$ distances. Fe is surrounded by $12 \mathrm{Fe}$ at $3.83 \AA$ in pyrite, and $\mathrm{Hg}$ by $2 \mathrm{Hg}$ at $3.75 \AA, 4 \mathrm{Hg}$ at $4.10 \AA$, and $6 \mathrm{Hg}$ at $4.15 \AA$ in $\alpha-\mathrm{HgS}^{29}$ The $\mathrm{Hg}-\mathrm{Hg}$ distances are respectively $2 \%$ shorter, $7 \%$ longer and $8 \%$ longer than the Fe-Fe distances. This steric compatibility is augmented by the flexibility of the Fe-S-Fe 
interpolyhedral bond angles across the 2 × $6=12$ shared octahedral corners (Figure 1a). We conclude from this, and from the estimated variation of the $\mathrm{Hg}$ content in the most concentrated coal sample $(\mathrm{C}$ 182, Meghalaya), that pyrite can accommodate in solid solution as much as ca. $300-500 \mathrm{ppm} \mathrm{Hg}$.

Bonding environment of $\mathbf{H g}$ in pyrite from sedimentary rock. The two sedimentary pyrites and the marcasite reference, also from a sedimentary rock, have nearly identical HR-XANES spectra (Figure S10). A sharper near-edge peak distinguishes this group from coal pyrite (Figure 4c). This difference is attributable to a more straight $\mathrm{S}-\mathrm{Hg}-\mathrm{S}$ bond in the sedimentary pyrite. The marcasite structure consists of single chains of edge-sharing $\mathrm{FeS}_{6}$ octahedra cross-linked by corners (Figure 1a). The coexistence in the structure of shared edges and corners lowers the symmetry from cubic in pyrite $(\mathrm{Pa}-3)$ to orthorhombic in marcasite (Pnnm), and splits the Fe-S distance from $2.26 \AA$ to 2 x $2.24 \AA+4 \times 2.25 \AA{ }^{32}$ The pairing of the six $3 \mathrm{~d}$ electrons in low-spin nominally divalent iron maintains a near octahedral Oh symmetry at the Fe site in marcasite. The $2+4 \mathrm{Fe}$ coordination of marcasite is, however, a better geometric match to the $2+4 \mathrm{Hg}$ coordination than the cubic $\mathrm{Oh} \mathrm{Fe} \mathrm{site} \mathrm{of} \mathrm{pyrite.} \mathrm{The} \mathrm{structural} \mathrm{distinction} \mathrm{among} \mathrm{the} \mathrm{Fe}$ sites in pyrite and marcasite offers an explanation for the near-edge sharpening observed in sedimentary pyrite relative to coal pyrite (Figure 4c). In summary, the sensitivity of region A to the S-Hg-S bond angle provides a signature for the orthorhombic distortion of the cubic pyrite structure and a spectroscopic tool to detect microscopic marcasite lamellae in bulk pyrite.

Bonding environment of $\mathbf{H g}$ in hydrothermal pyrite. The three Goldstrike samples (H-17, H-24, H-60) have identical HR-XANES signatures which differentiate them from the other pyrite samples: The near-edge peak in region $\mathrm{A}$ is considerably reduced in amplitude; a prominent shoulder is present in region $\mathrm{B}$; and the absorption in region $\mathrm{C}$ is clearly shifted to lower energy (Figure $\mathrm{S} 11$ ). These spectra are in fact intermediate between those from the two previous groups of pyrites, on the one hand, and from $\beta-\mathrm{HgS}_{\mathrm{NP}}$, on the other hand, indicating that $\mathrm{Hg}(\mathrm{II})$ must be present as a mixture combination of the two main forms (Figure 5a). The best fit to the Goldstrike spectral group was obtained with $45 \pm 6 \%$ 
marcasite $+55 \pm 6 \% \beta-\mathrm{HgS}_{\mathrm{NP}}$ (fit residual, $\mathrm{NSS}=4.810^{-5}$ ) (Figure $5 \mathrm{~b}$, Table 2). The precision of the species percentages was estimated to be equal to the variation of their best-fit values obtained for a $20 \%$ variation of the fit quality (i.e., $30 \%$ increase of NSS). ${ }^{55,58-61}$ Replacing marcasite by coal pyrite degraded the fit by $21 \%\left(\mathrm{NSS}=5.810^{-5}\right)$. Thus, the marcasite-type and coal-type bonding environments cannot be distinguished with confidence in a mixture with $\beta-\mathrm{HgS}_{\mathrm{NP}}$.

With only $1.8 \mathrm{ppm} \mathrm{Hg}$, the pyrite crystal from Park City (Utah) was more difficult to measure. Despite a significantly worse signal/noise ratio, its spectrum is broadly intermediary between the Goldstrike group and marcasite/coal pyrite (Figure $\mathrm{S} 11$ ). The tetrahedral $\beta$-HgS $\mathrm{HP}_{\mathrm{N}}$ and $2+4 \mathrm{FeS}_{2}$-type coordinations still coexist in a mixture, but here the second form much prevails. Less total $\mathrm{Hg}$ signifies less $\beta$-HgS ${ }_{\mathrm{NP}}{ }^{5}$, 62

We conclude that $\beta-\mathrm{HgS}_{\mathrm{NP}}$ is a marker of this type of deposit, and may have formed by direct precipitation from hydrothermal fluid. Trigub et al. ${ }^{25}$ showed that $\mathrm{Au}(\mathrm{I})$ is dominantly transported as a $\mathrm{Au}(\mathrm{HS})_{2}{ }^{-}$complex in ore-forming fluids at weakly acidic to weakly alkaline $\mathrm{pH}$. Divalent $\mathrm{Hg}$ may be transported as the neutral species $\mathrm{Hg}(\mathrm{HS})_{2}$ in sulfide-rich supercritical fluids and may precipitate as $\beta$ $\mathrm{HgS}_{\mathrm{NP}}$ when the temperature decreases. The solubility product for $\beta-\mathrm{Hg} \mathrm{S}_{\mathrm{NP}}$ at elevated temperature and pressure is unknown, but at ambient condition it is extremely low in sulfidic solutions: $\log \mathrm{K}_{\mathrm{sp}}=-36.9$ $\left(\beta-\mathrm{HgS}_{(\mathrm{s})}+\mathrm{H}^{+}=\mathrm{Hg}^{2+}+\mathrm{HS}^{-}\right){ }^{63}$

Bonding environment of $\mathbf{H g}$ in the Idrija pyrite. A strong absorption at $12298 \mathrm{eV}$ of the Idrija HRXANES spectrum in region B clearly distinguishes it from all other pyrites (Figure 5c). This spectrum could not be reconstructed without elemental mercury $\left(\mathrm{Hg}^{0} \mathrm{~s}\right)$ as a fit component. The best two-component fit was obtained with $62 \%$ marcasite and $37 \% \mathrm{Hg}^{0}{ }_{\mathrm{s}}\left(\mathrm{NSS}=3.210^{-4}\right.$ ) (Figure 5d, Table 2). This model fit fails to reproduce well the data in region $\mathrm{A}$ and $\mathrm{B}$, and addition of a third component proved unsuccessful. Perhaps the sample contains a third unidentified $\mathrm{Hg}$ form, or perhaps the quality of the $\mathrm{Hg}_{\mathrm{s}}^{0}$ spectrum is not optimal. With a $\mathrm{Hg}_{\mathrm{s}}{ }_{\mathrm{s}}$ density of $13.5 \mathrm{~g} / \mathrm{cm}^{3}$, overabsorption dramatically distorts the relative intensity 
of the $\mathrm{Hg}-\mathrm{Hg}$ peaks measured in fluorescence. ${ }^{64} \mathrm{Jew}$ et al. ${ }^{65}$ reported that flash freezing can result in a $\mathrm{Hg}$ glass with loss of the $\mathrm{Hg}-\mathrm{Hg}$ contributions. Although our reference spectrum is well-structured and does not appear to suffer from this problem, this effect may cause artifacts in the data.

The Idrija mercury mineralization is hosted in Permo-Triassic sediments, intensely faulted by a rifting activity in the Middle Triassic. ${ }^{66}$ The main mercury minerals are $\alpha-\mathrm{HgS}$ and native $\mathrm{Hg}$ with minor $\beta$ $\mathrm{HgS}$. The pyrite specimen contains as much as 7.41 weight $\% \mathrm{Hg}$ (Table 1 ), of which $37 \mathrm{~mol} \%$ is native $\mathrm{Hg}$. Therefore, on a weight basis this sample has $27 \mathrm{mg} \mathrm{Hg}^{0} / \mathrm{g} \mathrm{FeS}_{2}$. This amount is probably too high for $\mathrm{Hg}$ to occur as syngenetic inclusions within the $\mathrm{FeS}_{2}$ structure, like $\beta-\mathrm{HgS}_{\mathrm{NP}}$ in hydrothermal pyrite. The $\mathrm{Hg}^{0}$ droplets identified at $10-15 \mathrm{~K}$ by HR-XANES likely occur in microscopic fissures, like commonly observed for minute precipitates of metal oxide (e.g., $\mathrm{TiO}_{2}$ ) and sulfide (e.g., FeS, $\mathrm{CuS}, \mathrm{ZnS}$, $\left.\mathrm{PbS}, \mathrm{CuFeS}_{2}\right){ }^{18,67}$ Elemental mercury in pyrite grains may occur at other Idrija-type mercury sulfide deposits, also formed by the circulation of low-temperature hydrothermal solutions along sedimentary substrates. This includes the Carboniferous-Permian mercury mining district of Mieres in Asturias $(\text { Spain })^{12}$, and the New Idria mercury mine in California. ${ }^{11}$

\section{ENVIRONMENTAL IMPLICATIONS AND OUTLOOK FOR HR-XANES SPECTROSCOPY IN THE SPECIATION OF TRACE LEVELS OF MERCURY}

Over the past 50 years, mercury released to land and water due to anthropogenic activities has become the primary source of mercury contamination in the environment, reaching $7-8 \mathrm{Gg} \mathrm{yr}-1$ in $2010 .{ }^{68,69}$. The time-scale for mercury removal from soil and water is relatively long and ranges from years to millennia. ${ }^{70,71}$ In this context, many historical and active coal and metal mining activities were showed to be a significant source of mercury contamination and as such in need of mitigation and remediation strategies on a global level. ${ }^{68,72}$ Results from this study can help predict the environmental risk of mercury in new operations. With the speciation data obtained here for several genetic types of pyrite and 
further work on determining the nature of pyrite hosting $\mathrm{Hg}$ in other geological environments, a database on the $\mathrm{Hg}$ speciation can be developed. With such data, improved prediction can be made on the types and magnitudes of $\mathrm{Hg}$ releases that would arise from the oxidative dissolution of pyrite. Such speciation data can be built into acid mine drainage prediction, control and treatment plans at mine sites and be part of the environmental impact assessment studies.

Under oxidative conditions, such as those that may result from mining and processing operations, mercury released by the dissolution of pyrite can form soluble compounds and subject to methylation by sulfate reducing bacteria. ${ }^{73,74}$ High inorganic $(\mathrm{Hg}(\mathrm{II}))$ and organic $(\mathrm{MeHg})$ mercury concentrations have been reported on land and into water bodies surrounding the emission sources. ${ }^{59,75-79}$ As will be shown below, the divalent mercury ions, the $\beta-\mathrm{HgS}$ nanoparticles, and the droplets of liquid mercury identified here will have different pathways in the environment and may not pose the same threat to ecosystems.

Nearly all inorganic $\mathrm{Hg}(\mathrm{II})$ is bound to dissolved organic matter in aquatic systems. ${ }^{80,81}$ The free ionic mercury species can be complexed by extracellular low-molecular-weight (LMW) thiols ${ }^{82}$ resulting from microbial activity associated with the catalytic oxidation of pyrite. ${ }^{83,} 84 \mathrm{Hg}$ (II) bound to small organic molecules is bioavailable. ${ }^{82,85,86}$ Although $\beta-\mathrm{HgS}$ is chemically stable in oxygenated water, LMW thiols could also binds to, and dissolve, mercury from the bare nanosized particles and provide shuttle molecules facilitating $\mathrm{Hg}$ uptake by microorganisms. The $\beta$-HgS nanoparticles could also cross cellular membranes and exert potent cytotoxicity or increase MeHg production. ${ }^{87}$ Internalization of metal sulfide nanoparticles, such as $\mathrm{CuS}, \mathrm{ZnS}, \mathrm{As}_{4} \mathrm{~S}_{4}$, is well-documented (see e.g. Ref.. ${ }^{88,}{ }^{89,}{ }^{90}$ ). Therefore, organically-bound $\mathrm{Hg}(\mathrm{II})$ and nanoparticulate $\mathrm{Hg}(\mathrm{II})$ are potentially biologically available, and can be converted to methylmercury in sediment deposits and mine wastes. ${ }^{76,79}$ Owing to the preexisting occurrence of $\beta-\mathrm{HgS}_{\mathrm{NP}}$ in pyrite, methylation may occur in pore waters undersaturated with respect to $\mathrm{HgS}(\mathrm{s})$, which is contrary to current knowledge. ${ }^{63}$ In addition to being bioavailable, portions of the divalent mercury pool may be photoreduced to $\mathrm{Hg}^{0}$ and volatilized..$^{91,92}$ 
Elemental mercury from the droplets of liquid mercury $\left(\mathrm{Hg}^{0}\right)$ desorbed from the microfissures of pyrite upon dissolution is likely to evade into the atmosphere because $\mathrm{Hg}^{0}{ }_{1}$ has a low heat of vaporization $\left(14.5 \mathrm{kcal} \mathrm{mol}^{-1}\right.$ at $\left.20^{\circ} \mathrm{C}^{93}\right)$. Light- and temperature-induced volatilization of $\mathrm{Hg}^{0}$ liquid has been observed in soil and in Au and $\mathrm{Hg}$ mines. ${ }^{12,65,94-96}$ Elemental mercury is relatively unreactive chemically, and its conversion to $\mathrm{Hg}(\mathrm{II})$ by photooxidation is not a predominant process. ${ }^{92}$

Mercury $\mathrm{L}_{3}$-edge HR-XANES spectroscopy has proven to be a powerful tool for the characterization of the coordination and local structure of $\mathrm{Hg}$ in natural $\mathrm{FeS}_{2}$. Using the spectra of model compounds as fingerprints, it was possible (1) to distinguish the $\mathrm{Hg}$ forms incorporated in the $\mathrm{FeS}_{2}$ structure and precipitated as nanoparticulate $\beta-\mathrm{HgS}$ and liquid $\mathrm{Hg}^{0}$, and (2) to determine the proportions of the three species (Table 2). Because of its enhanced sensitivity to short-range order, HR-XANES spectroscopy gives more reliable information than EXAFS spectroscopy when applied to disordered and finely particulate materials. ${ }^{55}$ HR-XANES should find a wide array of application for speciation study of very high $\mathrm{Z}$ elements, including third row transition metals and actinides, in environmental materials because their coordination is usually extremely distorted and often diverse. Moreover, even higher spectral resolution than the one obtained here at the $\mathrm{Hg} \mathrm{L}_{3}$ edge $(12.3 \mathrm{keV})$ can be obtained at the $\mathrm{M}_{4}$ edge for radionuclides ( $\sim 3.5-3.8 \mathrm{keV})$ because the $\mathrm{M}_{\beta}$ emission lines are narrower than the $\mathrm{L}_{\alpha}$ lines. The superior advantage of $\mathrm{M}_{4}$ edge HR-XANES spectroscopy for these elements has been documented recently on mixed-valent uranium in magnetite nanoparticles. ${ }^{97}$ These measurements were conducted on concentrated samples at an experimental U loading of 1000 ppm and higher. A high-luminosity tenderenergy multi-analyzer spectrometer is being commissioned on beamline ID26 at the ESRF to bring the detection limit at low energy down to a few tens of ppm.

\section{ASSOCIATED CONTENT}

Supporting Information is available free of charge 
Detailed sample description and preparation, EPMA, ICP-OES, and ICP-MS analyses, HR-XANES measurements, Tables S1-S5, Figures S1-S11, HR- ${ }^{18,66}$ XANES data.

\section{AUTHOR INFORMATION}

\section{Corresponding Authors}

E-mail: alain.manceau@univ-grenoble-alpes.fr

\section{Notes}

The authors declare no competing financial interests.

\section{ACKNOWLEGMENTS}

Support was provided to A.M. and P.G. by the ANR under Grant ANR-10-EQPX-27-01 (EcoX Equipex). The DMA-80 Hg analyses were performed by Aude Wack.

\section{REFERENCES}

(1) Huerta-Diaz, M. A.; Morse, J. W., Pyritization of trace-metals in anoxic marine-sediments. Geochim. Cosmochim. Acta 1992, 56, 2681-2702.

(2) Feng, X.; Hong, Y., Modes of occurrence of mercury in coals from Guizhou, People's Republic of China. Fuel 1999, 78, 1181-1188.

(3) Zhang, J. Y.; Ren, D.; Zheng, C. G.; Zeng, R. S.; Chou, C. L.; Liu, J., Trace element abundances in major minerals of Late Permian coals from southwestern Guizhou province, China. Intern. J. Coal Geol. 2002, 53, 55-64.

(4) Sakulpitakphon, T.; Hower, J. C.; Schram, W. H.; Ward, C. R., Tracking mercury from the mine to the power plant: geochemistry of the Manchester coal bed, Clay County, Kentucky. Intern. J. Coal Geol. 2004, 57, 127-141.

(5) Reich, M.; Kesler, S. E.; Utsunomiya, S.; Palenik, C. S.; Chryssoulis, S. L.; Ewing, R. C., Solubility of gold in arsenian pyrite. Geochim. Cosmochim. Acta 2005, 69, 2781-2796. 
(6) Hower, J. C.; Campbell, J. L.; Teesdale, W. J.; Nejedly, Z.; Robertson, J. D., Scanning proton microprobe analysis of mercury and other trace elements in Fe-sulfides from a Kentucky coal. Intern. J. Coal Geol. 2008, 75, 88-92.

(7) Diehl, S. F.; Goldhaber, M. B.; Koenig, A. E.; Lowers, H. A.; Ruppert, L. F., Distribution of arsenic, selenium, and other trace elements in high pyrite Appalachian coals: Evidence for multiple episodes of pyrite formation. Intern. J. Coal Geol. 2012, 94, 238-249.

(8) Kolker, A., Minor element distribution in iron disulfides in coal: A geochemical review. Intern. J. Coal Geol. 2012, 94, 32-43.

(9) Qureshi, A.; Maurice, C.; Ohlander, B., Potential of coal mine waste rock for generating acid mine drainage. J. Geochem. Explor. 2016, 160, 44-54.

(10) Finkelman, R. B.; Palmer, C. A.; Wang, P. P., Quantification of the modes of occurrence of 42 elements in coal. Intern. J. Coal Geol. 2018, 185, 138-160.

(11) Ganguli, P. M.; Mason, R. P.; Abu-Saba, K. E.; Anderson, R. S.; Flegal, A. R., Mercury speciation in drainage from the New Idria mercury mine, California. Environ. Sci. Technol. 2000, 34, 4773-4779.

(12) Loredo, J.; Alvarez, R.; Ordonez, A., Release of toxic metals and metalloids from Los Rueldos mercury mine (Asturias, Spain). Sci. Tot. Environ. 2005, 340, 247-260.

(13) Sierra, C.; Saiz, J. R. A.; Gallego, J. L. R., Nanofiltration of acid mine drainage in an abandoned mercury mining area. Water Air Soil Poll. 2013, 224, 1734.

(14) Feng, X.; Qiu, G., Mercury pollution in Guizhou, Southwestern China - An overview Sci. Tot. Environ. 2008, 400, 227-237.

(15) Pirrone, N.; Cinnirella, S.; Feng, X.; Finkelman, R. B.; Friedli, H. R.; Leaner, J.; Mason, R.; Mukherjee, A. B.; Stracher, G. B.; Streets, D. G.; Telmer, K., Global mercury emissions to the atmosphere from anthropogenic and natural sources. Atmosph. Chem. Phys. 2010, 10, (13), 5951-5964.

(16) Wilcox, J.; Rupp, E.; Ying, S. C.; Lim, D. H.; Negreira, A. S.; Kirchofer, A.; Feng, F.; Lee, K., Mercury adsorption and oxidation in coal combustion and gasification processes. Intern. J. Coal Geol. 2012, 90, 4-20.

(17) Driscoll, C. T.; Mason, R. P.; Chan, H. M.; Jacob, D. J.; Pirrone, N., Mercury as a global pollutant: Sources, pathways, and effects. Environ. Sci. Technol. 2013, 47, 4967-4983.

(18) Deditius, A. P.; Utsunomiya, S.; Reich, M.; Kesler, S. E.; Ewing, R. C.; Hough, R.; Walshe, J., Trace metal nanoparticles in pyrite. Ore Geol. Rev. 2011, 42, 32-46.

(19) Paquette, K. E.; Helz, G. R., Inorganic speciation of mercury in sulfidic waters: the importance of zero-valent sulfur. Environ. Sci. Technol. 1997, 31, 2148-2153. 
(20) Ballirano, P.; Botticelli, M.; Maras, A., Thermal behaviour of cinnabar, $\alpha-\mathrm{HgS}$, and the kinetics of the $\beta-\mathrm{HgS}$ (metacinnabar) $\rightarrow \alpha-\mathrm{HgS}$ conversion at room temperature. Eur. J. Miner. 2013, 25, 957-965. (21) Dickson , F. W.; Tunell, G., The stability relations of cinnabar and metacinnabar. Am. Miner. 1959, $44,471-487$.

(22) Paszkowicz, W.; Szuszkiewicz, W.; Szamota-Sadowska, K.; Domagala, J. Z.; Witkowska, B.; Marczak, M.; Zinn, P., X-ray diffraction study of sphalerite-cinnabar phase transition in $\mathrm{Hg}_{0.985} \mathrm{Co}_{0.015 \mathrm{~S}}$. Mater. Str. 1999, 6, 102-102.

(23) Manceau, A.; Lemouchi, C.; Enescu, M.; Gaillot, A.-C.; Lanson, M.; Magnin, V.; Glatzel, P.; Poulin, B. A.; Ryan, J. N.; Aiken, G. R.; Gautier-Luneau, I.; Nagy, K. L., Formation of mercury sulfide from $\mathrm{Hg}(\mathrm{II})$-thiolate complexes in natural organic matter. Environ. Sci. Technol. 2015, 49, 9787-9796.

(24) Shannon, R. D., Revised effective ionic radius and systematic studies of interatomic distances in halides and chalcogenides. Acta Crystallogr. 1976, B25, 925-946.

(25) Trigub, A. L.; Tagirov, B. R.; Kvashnina, K. O.; Lafuerza, S.; Filimonova, O. N.; Nickolsky, M. S., Experimental determination of gold speciation in sulfide-rich hydrothermal fluids under a wide range of redox conditions. Chem. Geol. 2017, 471, 52-64.

(26) Reeder, R.; Lamble, G. M.; Northrup, P. A., XAFS study of the coodination and local relaxaton around $\mathrm{Co}^{2+}, \mathrm{Zn}^{2+}, \mathrm{Pb}^{2+}$, and $\mathrm{Ba}^{2+}$ trace elements in calcite. Am. Miner. 1999, 84, 1049-1060.

(27) Manceau, A.; Nagy, K. L., Relationships between $\mathrm{Hg}(\mathrm{II})-\mathrm{S}$ bond distance and $\mathrm{Hg}(\mathrm{II})$ coordination in thiolates. Dalton Trans. 2008, 11, 1421-1425.

(28) Dudev, M.; Wang, J.; Dudev, T.; Lim, C., Factors governing the metal coordination number in metal complexes from Cambridge structural database analyses. J. Phys. Chem. B 2006, 110, 1889-1895. (29) Auvray, P.; Genet, F., Affinement de la structure cristalline du cinabre $\alpha-H g S$. Bull. Soc. Fr. Miner. Cristallogr. 1973, 96, 218-219.

(30) Ishikawa, K.; Isonaga, T.; Wakita, S.; Suzuki, Y., Structure and electrical-properties of Au2S. Solid State Ionics 1995, 79, 60-66.

(31) Pokrovski, G. S.; Tagirov, B. R.; Schott, J.; Hazemann, J. L.; Proux, O., A new view on gold speciation in sulfur-bearing hydrothermal fluids from in situ X-ray absorption spectroscopy and quantum-chemical modeling. Geochim. Cosmochim. Acta 2009, 73, 5406-5427.

(32) Rieder, M.; Crelling, J. C.; Sustai, O.; Drabek, M.; Weiss, Z.; Klementova, M., Arsenic in iron disulfides in a brown coal from the North Bohemian Basin, Czech Republic. Intern. J. Coal Geol. 2007, $71,115-121$. 
(33) Trigub, A. L.; Tagirov, B. R.; Kvashnina, K. O.; Chareev, D. A.; Nickckolsky, M. S.; Shiryaev, A. A.; Baranova, N. N.; Kovalchuk, E. V.; Mokhov, A. V., X-ray spectroscopy study of the chemical state of "invisible" Au in synthetic minerals in the Fe-As-S system. Am. Miner. 2017, 102, 1057-1065.

(34) Ding, Z. H.; Zheng, B. S.; Long, J. P.; Belkin, H. E.; Finkelman, R. B.; Chen, C. G.; Zhou, D. X.; Zhou, Y. S., Geological and geochemical characteristics of high arsenic coals from endemic arsenosis areas in southwestern Guizhou Province, China. Appl. Geochem. 2001, 16, 1353-1360.

(35) Lefticariu, L.; Blum, J. D.; Gleason, J. D., Mercury isotopic evidence for multiple mercury sources in coal from the Illinois Basin. Environ. Sci. Technol. 2011, 45, 1724-1729.

(36) Kolker, A.; Panov, B. S.; Panov, Y. B.; Landa, E. R.; Conko, K. M.; Korchemagin, V. A.; Shendrik, T.; McCord, J. D., Mercury and trace element contents of Donbas coals and associated mine water in the vicinity of Donetsk, Ukraine. Intern. J. Coal Geol. 2009, 79, (3), 83-91.

(37) Diehl, S. F.; Goldhaber, M. B.; Hatch, J. R., Modes of occurrence of mercury and other trace elements in coals from the warrior field, Black Warrior Basin, Northwestern Alabama. Intern. J. Coal Geol. 2004, 59, 193-208.

(38) Zhou, T. F.; Fan, Y.; Yuan, F.; Wu, M. A.; Hou, M. J.; Voicu, G.; Hu, Q. H.; Zhang, Q. M.; Yue, S. C., A preliminary geological and geochemical study of the Xiangquan thallium deposit, eastern China: the world's first thallium-only mine. Miner. Petrol. 2005, 85, 243-251.

(39) Deditius, A. P.; Utsunomiya, S.; Renock, D.; Ewing, R. C.; Ramana, C. V.; Becker, U.; Kesler, S. E., A proposed new type of arsenian pyrite: Composition, nanostructure and geological significance. Geochim. Cosmochim. Acta 2008, 72, 2919-2933.

(40) Deditius, A. P.; Reich, M.; Kesler, S. E.; Utsunomiya, S.; Chryssoulis, S. L.; Walshe, J.; Ewing, R. C., The coupled geochemistry of Au and As in pyrite from hydrothermal ore deposits. Geochim. Cosmochim. Acta 2014, 140, 644-670.

(41) Simon, G.; Huang, H.; Penner-Hahn, J. E.; Kesler, S. E.; Kao, L. S., Oxidation state of gold and arsenic in gold-bearing arsenian pyrite. Am. Miner. 1999, 84, 1071-1079.

(42) Zhang, M.; Konishi, H.; Xu, H. F.; Sun, X. M.; Lu, H. F.; Wu, D. D.; Wu, N. Y., Morphology and formation mechanism of pyrite induced by the anaerobic oxidation of methane from the continental slope of the NE South China Sea. J. Asian Earth Sci. 2014, 92, 293-301.

(43) Mishra, B.; Shoenfelt, E.; Yu, Q.; Yee, N.; Fein, J. B.; Myneni, S. C. B., Stoichiometry of mercurythiol complexes on bacterial cell envelopes. Chem. Geol. 2017, 464, 137-146.

(44) Thomas, S. A.; Gaillard, J. F., Cysteine addition promotes sulfide production and four-fold $\mathrm{Hg}(\mathrm{II})$ S coordination in actively metabolizing Escherichia coli. Environ. Sci. Technol. 2017, 51, 4642-4651. 
(45) Marcus, M. A.; Chen, H. S.; Espinosa, G. P.; Tsai, C. L., Distance distributions about Mn in icosahedral and crystalline Al Mn Si. Solid State Comm. 1986, 58, 227-230.

(46) Crozier, E. D., A review of the current status of XAFS spectroscopy. Nucl. Instrum. Meth. B 1997, $133,134-144$.

(47) Chan, J.; Merrifield, M. E.; Soldatov, A. V.; Stillman, M. J., XAFS spectral analysis of the cadmium coordination geometry in cadmium thiolate clusters in metallothionein. Inorg. Chem. 2005, 44, 4923-4933.

(48) Penner-Hahn, J. E., Characterization of 'spectroscopically quiet' metals in biology. Coordin. Chem. Rev. 2005, 249, 161-177.

(49) Henderson, G. S.; de Groot, F. M. F.; Moulton, B. J. A., X-ray Absorption Near-Edge Structure (XANES) Spectroscopy. In Spectroscopic Methods in Mineralology and Materials Sciences, Henderson, G. S.; Neuville, D. R.; Downs, R. T., Eds. 2014; Vol. 78, pp 75-138.

(50) George, G. N.; Singh, S. P.; Prince, R. C.; Pickering, I. J., Chemical forms of mercury and selenium in fish following digestion with simulated gastric fluid. Chem. Res. Toxicol. 2008, 21, 2106-2110.

(51) Campbell, J. L.; Papp, T., Widths of the atomic K-N7 levels. Atomic Data Nucl. Data Tables 2001, 77, 1-56.

(52) Glatzel, P.; Bergmann, U., High resolution 1s core hole X-ray spectroscopy in 3d transition metal complexes_electronic and structural information. Coord. Chem. Rev. 2005, 249, 65-95.

(53) Rovezzi, M.; Lapras, C.; Manceau, A.; Glatzel, P.; Verbeni, R., High energy-resolution x-ray spectroscopy at ultra-high dilution with spherically bent crystal analyzers of $0.5 \mathrm{~m}$ radius. Rev. Sci. Instr. 2017, 88, 013108.

(54) Manceau, A.; Enescu, M.; Simionovici, A.; Lanson, M.; Gonzalez-Rey, M.; Rovezzi, M.; Tucoulou, R.; Glatzel, P.; Nagy, K. L.; Bourdineaud, J.-P., Chemical forms of mercury in human hair reveal sources of exposure. Environ. Sci. Technol. 2016, 50, 10721-10729.

(55) Manceau, A.; Wang, J.; Rovezzi, M.; Glatzel, P.; Feng, X., Biogenesis of mercury-sulfur nanoparticles in plant leaves from atmospheric gaseous mercury. Environ. Sci. Technol. 2018, 52, 39353948.

(56) Manceau, A.; Lemouchi, C.; Rovezzi, M.; Lanson, M.; Glatzel, P.; Nagy, K. L.; Gautier-Luneau, I.; Joly, Y.; Enescu, M., Structure, bonding, and stability of mercury complexes with thiolate and thioether ligands from high-resolution XANES spectroscopy and first-principles calculations. Inorg. Chem. 2015, 54, 11776-11791. 
(57) Bianconi, A.; Dell'Ariccia, M.; Gargano, A.; Natoli, C. R., Bond length determination using XANES. In EXAFS Near Edge Struc., Bianconi, A.; Incoccia, A.; Stipcich, S., Eds. Springer, Berlin: 1983; Vol. 27, pp 57-61.

(58) Isaure, M. P.; Laboudigue, A.; Manceau, A.; Sarret, G.; Tiffreau, C.; Trocellier, P.; Hazemann, J. L.; Chateigner, D., Quantitative Zn speciation in a contaminated dredged sediment by $\mu \mathrm{PIXE}, \mu \mathrm{SXRF}$, EXAFS spectroscopy and principal component analysis. Geochim. Cosmochim. Acta 2002, 66, 15491567.

(59) Kim, C. S.; Bloom, N. S.; Rytuba, J. J.; Brown, G. E., Mercury speciation by X-ray absorption fine structure spectroscopy and sequential chemical extractions: A comparison of speciation methods. Environ. Sci. Technol. 2003, 37, 5102-5108.

(60) Senn, A. C.; Kaegi, R.; Hug, S. J.; Hering, J. G.; Mangold, S.; Voegelin, A., Composition and structure of $\mathrm{Fe}(\mathrm{III})$-precipitates formed by $\mathrm{Fe}(\mathrm{II})$ oxidation in water at near-neutral $\mathrm{pH}$ : Interdependent effects of phosphate, silicate and Ca. Geochim. Cosmochim. Acta 2015, 162, 220-246.

(61) Voegelin, A.; Pfenninger, N.; Petrikis, J.; Majzlan, J.; Plotze, M.; Senn, A. C.; Mangold, S.; Steininger, R.; Gottlicher, J., Thallium speciation and extractability in a thallium- and arsenic-rich soil developed from mineralized carbonate rock. Environ. Sci. Technol. 2015, 49, 5390-5398.

(62) Deditius, A. P.; Reich, M., Constraints on the solid solubility of Hg, Tl, and Cd in arsenian pyrite. Am. Miner. 2016, 101, 1451-1459.

(63) Drott, A.; Björn, E.; Boucher, S.; Skyllberg, U., Refining thermodynamic constants for mercury(II)-sulfides in equilibrium with metacinnabar at sub-micromolar aqueous sulfide concentrations. Environ. Sci. Technol. 2013, 47, 4197-4203.

(64) Manceau, A.; Marcus, M. A.; Tamura, N., Quantitative speciation of heavy metals in soils and sediments by synchrotron X-ray techniques. In Applications of Synchrotron Radiation in LowTemperature Geochemistry and Environmental Science, Fenter, P. A.; Rivers, M. L.; Sturchio, N. C.; Sutton, S. R., Eds. Mineralogical Society of America: Washington, DC, 2002; Vol. 49, pp 341-428.

(65) Jew, A. D.; Kim, C. S.; Rytuba, J. J.; Gustin, M. S.; Brown, G. E., New technique for quantification of elemental $\mathrm{Hg}$ in mine wastes and its implications for mercury evasion into the atmosphere. Environ. Sci. Technol. 2011, 45, 412-417.

(66) Palinkas, L.; Strmic, S.; Spangenberg, J.; Prochaska, W.; Herlec, U., Ore-forming fluids in the Grubler orebody, Idrija mercury deposit, Slovenia. Schweiz. Miner. Und Petrogr. 2004, 84, 173-188.

(67) Franchini, M.; McFarlane, C.; Maydagan, L.; Reich, M.; Lentz, D. R.; Meinert, L.; Bouhier, V., Trace metals in pyrite and marcasite from the Agua Rica porphyry-high sulfidation epithermal deposit, 
Catamarca, Argentina: Textural features and metal zoning at the porphyry to epithermal transition. Ore Geol. Rev. 2015, 66, 366-387.

(68) Kocman, D.; Horvat, M.; Pirrone, N.; Cinnirella, S., Contribution of contaminated sites to the global mercury budget. Environ. Res. 2013, 125, 160-170.

(69) Streets, D. G.; Horowitz, H. M.; Jacob, D. J.; Lu, Z.; Levin, L.; Ter Schure, A. F.; Sunderland, E. M., Total mercury released to the environment by human activities. Environ. Sci. Technol. 2017, 51, 5969-5977.

(70) Amos, H. M.; Jacob, D. J.; Streets, D. G.; Sunderland, E. M., Legacy impacts of all-time anthropogenic emissions on the global mercury cycle. Global Biogeochem. Cycles 2013, 27, 410-421.

(71) Amos, H. M.; Jacob, D. J.; Kocman, D.; Horowitz, H. M.; Zhang, Y.; Dutkiewicz, S.; Horvat, M.; Corbitt, E. S.; Krabbenhoft, D. P.; Sunderland, E. M., Global biogeochemical implications of mercury discharges from rivers and sediment burial. Environ. Sci. Technol. 2014, 48, 9514-9522.

(72) Hudson-Edwards, K., Tackling mine wastes. Science 2016, 352, 288-290.

(73) Rytuba, J. J., Mercury mine drainage and processes that control its environmental impact. Sci. Tot. Environ. 2000, 260, 57-71.

(74) Blowes, D. W.; Ptacek, C. J.; Jambor, J. L.; Weisener, C. G.; Paktunc, D.; Gould, W. D.; Johnson, D. B., The geochemistry of acid mine drainage. In Treatise on Geochemistry (second edition), Holland, H. D.; Turekian, K. K., Eds. Elsevier, Oxford: 2014; Vol. 11, pp 131-190.

(75) Bonzongo, J. C.; Heim, K. J.; Warwick, J. J.; Lyons, W. B., Mercury levels in surface waters of the Carson River Lahontan Reservoir system, Nevada: Influence of historic mining activities. Environ. Poll. 1996, 92, 193-201.

(76) Marvin-DiPasquale, M.; Agee, J.; McGowan, C.; Oremland, R. S.; Thomas, M.; Krabbenhoft, D.; Gilmour, C. C., Methyl-mercury degradation pathways: A comparison among three mercury-impacted ecosystems. Environ. Sci. Technol. 2000, 34, 4908-4916.

(77) Hines, M. E.; Horvat, M.; Faganeli, J.; Bonzongo, J. C. J.; Barkay, T.; Major, E. B.; Scott, K. J.; Bailey, E. A.; Warwick, J. J.; Lyons, W. B., Mercury biogeochemistry in the Idrija River, Slovenia, from above the mine into the Gulf of Trieste. Environ. Res. 2000, 83, 129-139.

(78) Batten, K. M.; Scow, K. M., Sediment microbial community composition and methylmercury pollution at four mercury mine-impacted sites. Microb. Ecol. 2003, 46, 429-441.

(79) Gray, J. E.; Hines, M. E.; Higueras, P. L.; Adatto, I.; Lasorsa, B. K., Mercury speciation and microbial transformations in mine wastes, stream sediments, and surface waters at the Almaden Mining District, Spain. Environ. Sci. Technol. 2004, 38, 4285-4292. 
(80) Meili, M., Mercury in lakes and rivers. Metal Ions Biol. Syst. 1997, 34, 21-51.

(81) Haitzer, M.; Aiken, G. R.; Ryan, J. N., Binding of mercury(II) to dissolved organic matter: The role of the mercury-to-DOM concentration ratio. Environ. Sci. Technol. 2002, 36, 3564-3570.

(82) Leclerc, M.; Planas, D.; Amyot, M., Relationship between extracellular low-molecular-weight thiols and mercury species in natural lake periphytic biofilms. Environ. Sci. Technol. 2015, 49, 7709-7716.

(83) Taylor, B. E.; Wheeler, M. C.; Nordstrom, D. K., Isotope composition of sulfate in acid-mine drainage as measure of bacterial oxidation. Nature 1984, 308, 538-541.

(84) Balci, N.; Shanks, W. C.; Mayer, B.; Mandernack, K. W., Oxygen and sulfur isotope systematics of sulfate produced by bacterial and abiotic oxidation of pyrite. Geochim. Cosmochim. Acta 2007, 71, 3796-3811.

(85) Chiasson-Gould, S. A.; Blais, J. M.; Poulain, A. J., Dissolved organic matter kinetically controls mercury bioavailability to bacteria. Environ. Sci. Technol. 2014, 48, 3153-3161.

(86) Thomas, S. A.; Rodby, K.; Roth, E.; Jinsong Wu, J.; Gaillard, J. F., Spectroscopic and microscopic evidence of bio-mediated $\mathrm{HgS}$ species formation from $\mathrm{Hg}(\mathrm{II})$-cysteine complexes: implications for Hg(II) bioavailability. Environ. Sci. Technol. 2018, DOI: 10.1021/acs.est.8b01305.

(87) Benoit, J. M.; Gilour, C. C.; Mason, R. P., The influence of sulfide on solid-phase mercury bioavailability for methylation by pure cultures of Desulfobulbus propionicus (1pr3). Environ. Sci. Technol. 2001, 35, 127-132.

(88) Guo, Y. M.; Zhang, J.; Yang, L.; Wang, H. J.; Wang, F. F.; Zheng, Z., Syntheses of amorphous and crystalline cupric sulfide nanoparticles and study on the specific activities on different cells. Chem. Comm. 2010, 46, 3493-3495.

(89) Feswick, A.; Griffitt, R. J.; Siebein, K.; Barber, D. S., Uptake, retention and internalization of quantum dots in Daphnia is influenced by particle surface functionalization. Aquat. Toxicol. 2013, 130, 210-218.

(90) Wang, S. S.; Lv, J. T.; Ma, J. Y.; Zhang, S. Z., Cellular internalization and intracellular biotransformation of silver nanoparticles in Chlamydomonas reinhardtii. Nanotoxicol. 2016, 10, 11291135

(91) Lindberg, S. E.; Brooks, S.; Lin, C. J.; Scott, K. J.; Landis, M. S.; Stevens, R. K.; Goodsite, M.; Richter, A., Dynamic oxidation of gaseous mercury in the Arctic troposphere at polar sunrise. Environ. Sci. Technol. 2002, 36, 1245-1256. 
(92) O'Driscoll, N. J.; Siciliano, S. D.; Lean, D. R. S.; Amyot, M., Gross photoreduction kinetics of mercury in temperate freshwater lakes and rivers: Application to a general model of DGM dynamics. Environ. Sci. Technol. 2006, 40, 837-843.

(93) Lide, D. R., CRC handbook of chemistry and physics. CRC Press, Boca Raton: 1993.

(94) Boudala, F. S.; Folkins, I.; Beauchamp, S.; Tordon, R.; Neima, J.; Johnson, B., Mercury flux measurements over air and water in Kejimkujik National Park, Nova Scotia. Water Air Soil Poll. 2000, 122, 183-202.

(95) Gustin, M. S.; Coolbaugh, M. F.; Engle, M. A.; Fitzgerald, B. C.; Keislar, R. E.; Lindberg, S. E.; Nacht, D. M.; Quashnick, J.; Rytuba, J. J.; Sladek, C.; Zhang, H.; Zehner, R. E., Atmospheric mercury emissions from mine wastes and surrounding geologically enriched terrains. Environ. Geol. 2003, 43, 339-351.

(96) Garcia-Sanchez, A.; Contreras, F.; Adams, M.; Santos, F., Atmospheric mercury emissions from polluted gold mining areas (Venezuela). Environ. Geochem. Health 2006, 28, 529-540.

(97) Pidchenko, I.; Kvashnina, K. O.; Yokosawa, T.; Finck, N.; Bahl, S.; Schild, D.; Polly, R.; Bohnert, E.; Rossberg, A.; Gottlicher, J.; Dardenne, K.; Rothe, J.; Schafer, T.; Geckeis, H.; Vitova, T., Uranium Redox Transformations after U(VI) Coprecipitation with Magnetite Nanoparticles. Environ. Sci. Technol. 2017, 51, 2217-2225.

(98) Kravits, C. M.; Crelling, J. C., Effects of overbank deposition on the quality and maceral composition of the Herrin $\left(\mathrm{n}^{\circ} .6\right)$ coal (Pennsylvanian) of Southern Illinois. Intern. J. Coal Geol. 1981, $1,195-212$.

(99) Oliveira, M. L. S.; Marostega, F.; Taffarel, S. R.; Saikia, B. K.; Waanders, F. B.; DaBoit, K.; Baruah, B. P.; Silva, L. F. O., Nano-mineralogical investigation of coal and fly ashes from coal-based captive power plant (India): An introduction of occupational health hazards. Sci. Tot. Environ. 2014, 468, 1128-1137.

(100) Saikia, B. K.; Sharma, A.; Sahu, O. P.; Baruah, B. P., Study on physico-chemical properties, mineral matters and leaching characteristics of some Indian coals and fly ash. J. Geol. Soc. India 2015, $86,275-282$.

(101) Paktunc, D.; Kingston, D.; Pratt, A.; McMullen, J., Distribution of gold in pyrite and in products of its transformation resulting from roasting of refractory gold ore. Can. Miner. 2006, 44, 213-227.

(102) Paktunc, D., Speciation of arsenic in pyrite by micro-X-ray absorption fine-structure spectroscopy (XAFS). Ninth International Congress for Applied Mineralogy 2008, Brisbane, QLD, 8 - 10 September 2008. 


\section{FIGURE LEGENDS}

Figure 1. (a) Polyhedral associations in pyrite and marcasite. In pyrite, $\mathrm{FeS}_{6}$ octahedra are connected through vertices only. For clarity, only two polyhedral linkages are depicted. In marcasite, $\mathrm{FeS}_{6}$ octahedra are associated in single chains which are cross-linked laterally. (b) Hg coordinations in cinnabar and metacinnabar. $\mathrm{Hg}$ has a $2+4$ coordination in $\alpha-\mathrm{HgS}$ in which the two nearest S ligands are at $2.37 \AA$, much closer than the next four at $3.09 \AA$ and $3.29 \AA$. The three S-Hg-S pairs of bonds are nearly perpendicular. The $\beta-\mathrm{HgS}_{4}$ tetrahedron is regular (Oh symmetry).

Figure 2. (a) $\mathrm{Hg} \mathrm{L}_{3}$-edge XANES spectra from a two-coordinate $\mathrm{Hg}$-thiolate complex $\left(\mathrm{Hg}(\mathrm{SR})_{2}\right)$ measured in total fluorescence-yield mode (TFY, standard XANES) and at high energy-resolution (HRXANES). (b-e) Hg L3-edge HR-XANES spectra of references. Letters A, B, and C refer to indicator regions discussed in the text.

Figure 3. (a-c) Representative pyrite from Illinois Herrin (No. 6) coal. (a) Photomicrograph of framboidal pyrite associated with coal macerals. (b) Scanning electron microscope (SEM) image of framboidal pyrite. (c) Photomicrograph of massive, cleat-filling pyrite hosted in coal fractures (Figure S1). (d,e) Representative pyrite-quartz vein association in Meghalaya coal. d) Backscattered electron image, and e) zoomed area. The maximum size of pyrite grains in this area is $4 \mu \mathrm{m}$. Rutile, zircon, monazite, apatite and sillimanite grains dispersed in the coal matrix were also observed (Figure S4).

Figure 4. $\mathrm{Hg} \mathrm{L}_{3}$-edge HR-XANES spectra of coal pyrite concentrates and references. (a) Comparison with a two-coordinate RS-Hg-SR linear complex shows that $\mathrm{Hg}$ has a $2+k$ coordination in coal pyrite. (b) Comparison with $\alpha-\mathrm{HgS}$ shows that $k=4$ and that $\mathrm{Hg}$ is not clustered in coal pyrite (i.e., no $\mathrm{Hg}-\mathrm{Hg}$ 
pairs). (c) Sedimentary pyrite (S-3) has a sharper near-edge peak than coal pyrite, indicative of a more linear S-Hg-S coordination. The S-3 spectrum is nearly identical to that of marcasite (Figure S10), implying that $\mathrm{Hg}$ is incorporated in $\mathrm{S}-3$ in marcasite-type layers at the micrometer scale.

Figure 5. $\mathrm{Hg} \mathrm{L}_{3}$-edge HR-XANES spectra of hydrothermal pyrites. (a) The averaged Goldstrike spectrum is intermediate between the $\beta-\mathrm{HgS}_{\mathrm{NP}}$ and marcasite spectra. (b) Least-squares fit of the Goldstrike spectrum. (c,d) Idrija pyrite and fit. 
Table 1. List of samples

\begin{tabular}{|c|c|c|c|c|c|}
\hline Sample type & Code name & {$[\mathrm{Hg}], \mathrm{ppm}$} & Geological setting & Origin & Reference \\
\hline Coal, heavy ${ }^{\mathrm{a}}$ & C-49 & 48.6 & Pennsylvanian bituminous coal seam & Herrin $n^{\circ} 6$, Illinois, USA & Ref. ${ }^{35,98}$ \\
\hline Coal, light ${ }^{\mathrm{a}}$ & C-0.3 & 0.3 & - & - & \\
\hline Coal, heavy ${ }^{a}$ & C-182 & 182.3 & Sub-bituminous coal & Meghalaya, Bapung, India & Ref. 99,100 \\
\hline Coal, light ${ }^{a}$ & $\mathrm{C}-2$ & 2.5 & - & - & \\
\hline Pyrite $^{b}$ & $\mathrm{H}-2$ & 1.82 & Hydrothermal: Epithermal & Park City, Utah, USA & CANMET reference collection \\
\hline Pyrite $^{a}$ & $\mathrm{H}-17$ & 16.85 & Hydrothermal: Carlin-type & Goldstrike, Nevada, USA & Ref. ${ }^{101,102}$ \\
\hline Pyrite $^{a}$ & $\mathrm{H}-24$ & 23.7 & Hydrothermal: Carlin-type & Goldstrike, Nevada, USA & Ref. ${ }^{101,102}$ \\
\hline Pyrite $^{a}$ & $H-60$ & 60.9 & Hydrothermal: Carlin-type & Goldstrike, Nevada, USA & Ref. ${ }^{101,102}$ \\
\hline Pyrite $^{b}$ & S-3 & 2.63 & Sedimentary - Skarn & Neumark, Saxony, Germany & \\
\hline Pyrite $^{a}$ & $\mathrm{~S}-8$ & 7.85 & Sedimentary & Alzo, Gipuzkoa, Spain & \\
\hline Pyrite $^{a}$ & S-Idrija & $7.41 \%$ & Sedimentary & Idrija, Slovenia & Ref. $^{66}$ \\
\hline Marcasite $^{\mathrm{b}}$ & $M-6$ & 6.03 & Sedimentary & Komorany, Bohemia, Czech Republic & \\
\hline
\end{tabular}

Table 2. Proportion of the four Hg forms identified by HR-XANES

\begin{tabular}{|c|c|c|c|c|c|}
\hline Sample type & Code name & $\begin{array}{c}\mathrm{Hg} \text { for Fe } \\
\text { sub. in pyrite }\end{array}$ & $\begin{array}{l}\text { Hg for Fe } \\
\text { sub. in } \\
\text { marcasite }\end{array}$ & $\beta-\mathrm{HgS}_{\mathrm{NP}}$ & $\mathrm{Hg}_{\mathrm{s}}{ }_{\mathrm{s}}$ \\
\hline Coal deposit & C-0.3; C-2; C-49; C-182 & $100 \%$ & & & \\
\hline Carlin-type & $\mathrm{H}-17 ; \mathrm{H}-24 ; \mathrm{H}-60$ & & $45 \%$ & $55 \%$ & \\
\hline Sedimentary & S-3; S-8 & & $100 \%$ & & \\
\hline Idrija & S-Idrija & & $62 \%$ & & $37 \%$ \\
\hline
\end{tabular}




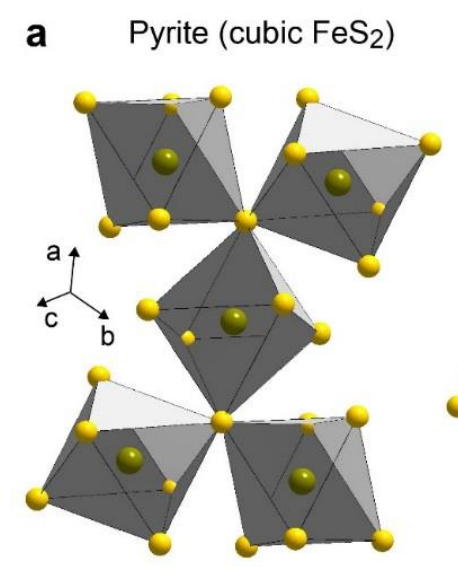

b

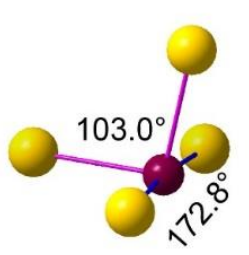

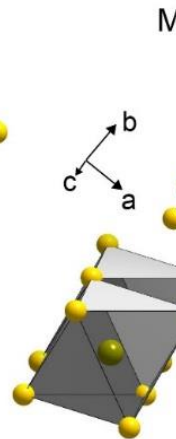

Marcasite (orth. $\mathrm{FeS}_{2}$ )

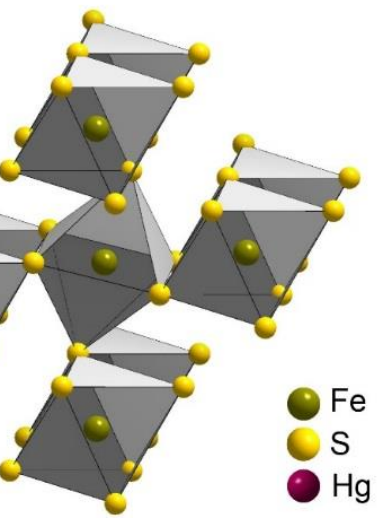

Metacinnabar ( $\beta$-HgS)

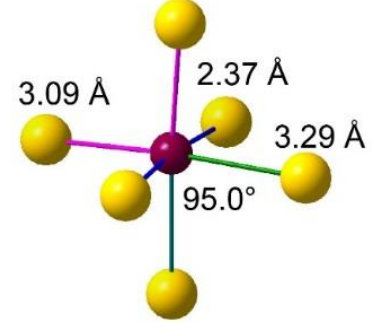

$2.53 \AA$

Figure 1

Please, print to fit the full width of one column, thank you 


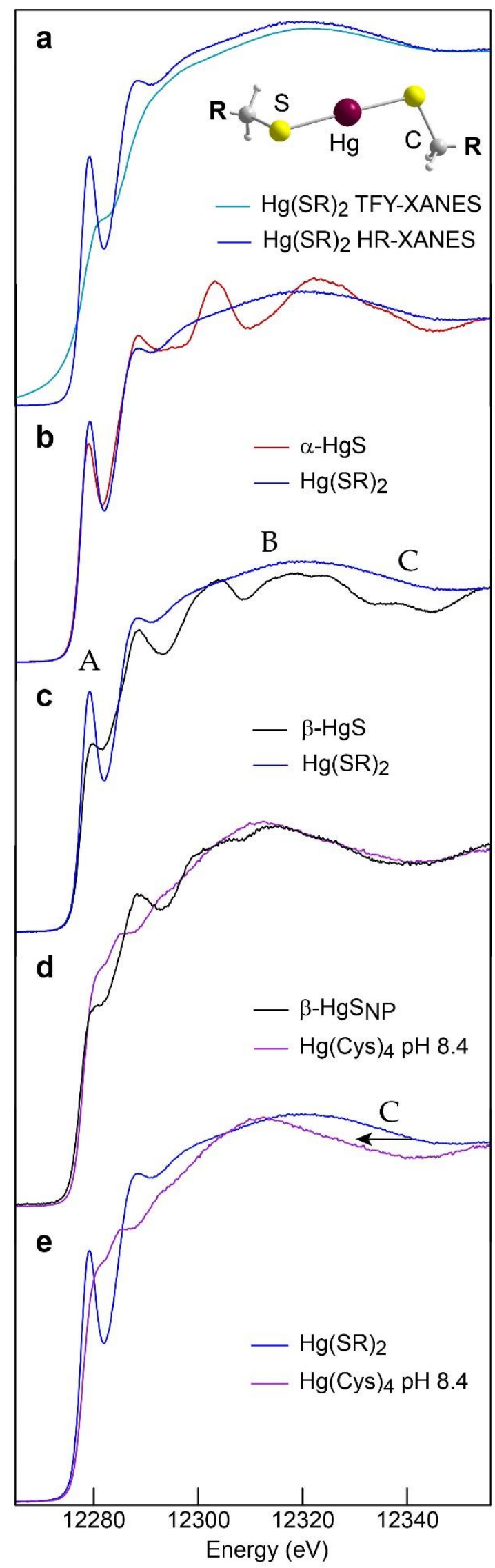

Figure 2 

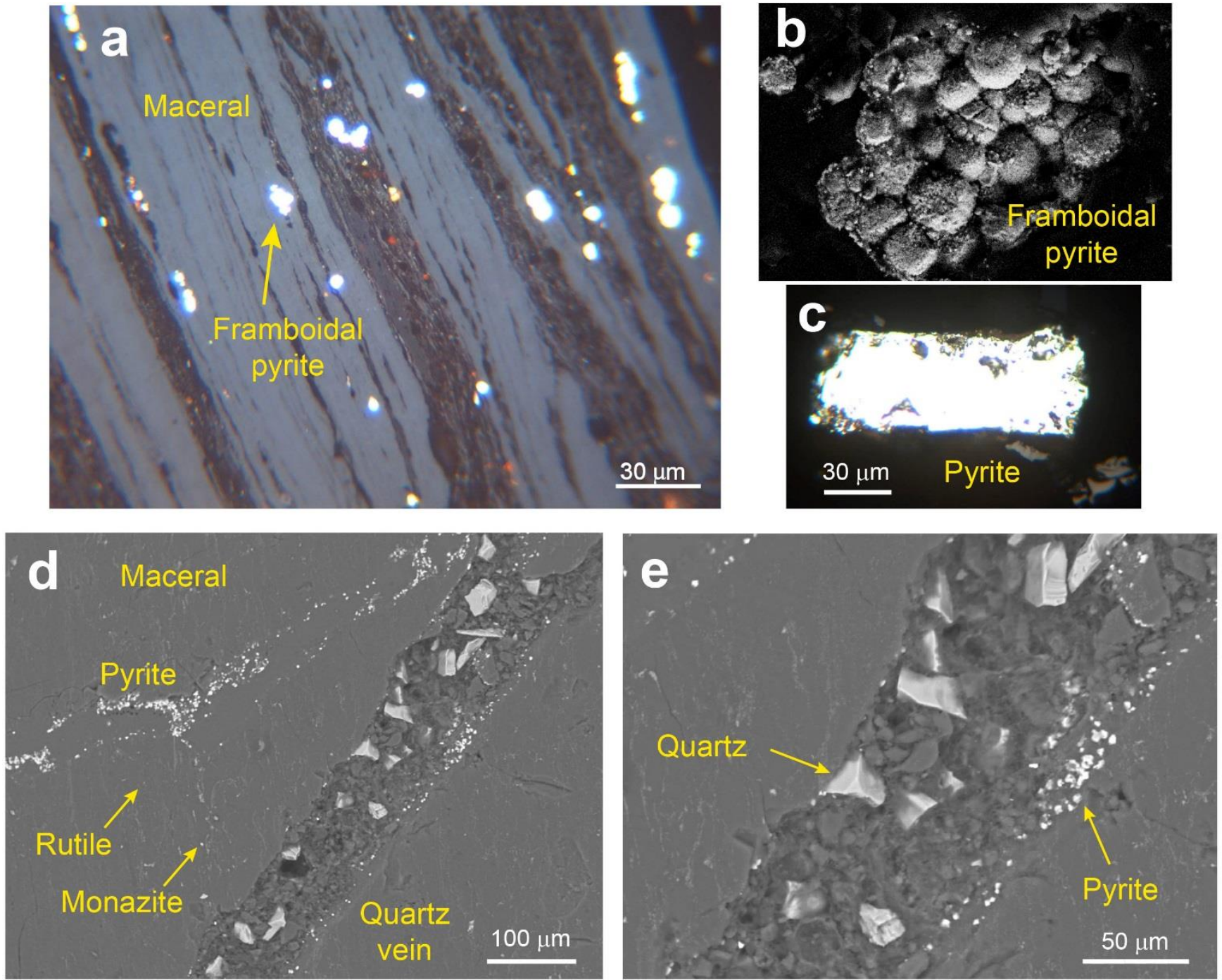

Figure 3

Please, print to fit the full width of two columns, thank you 


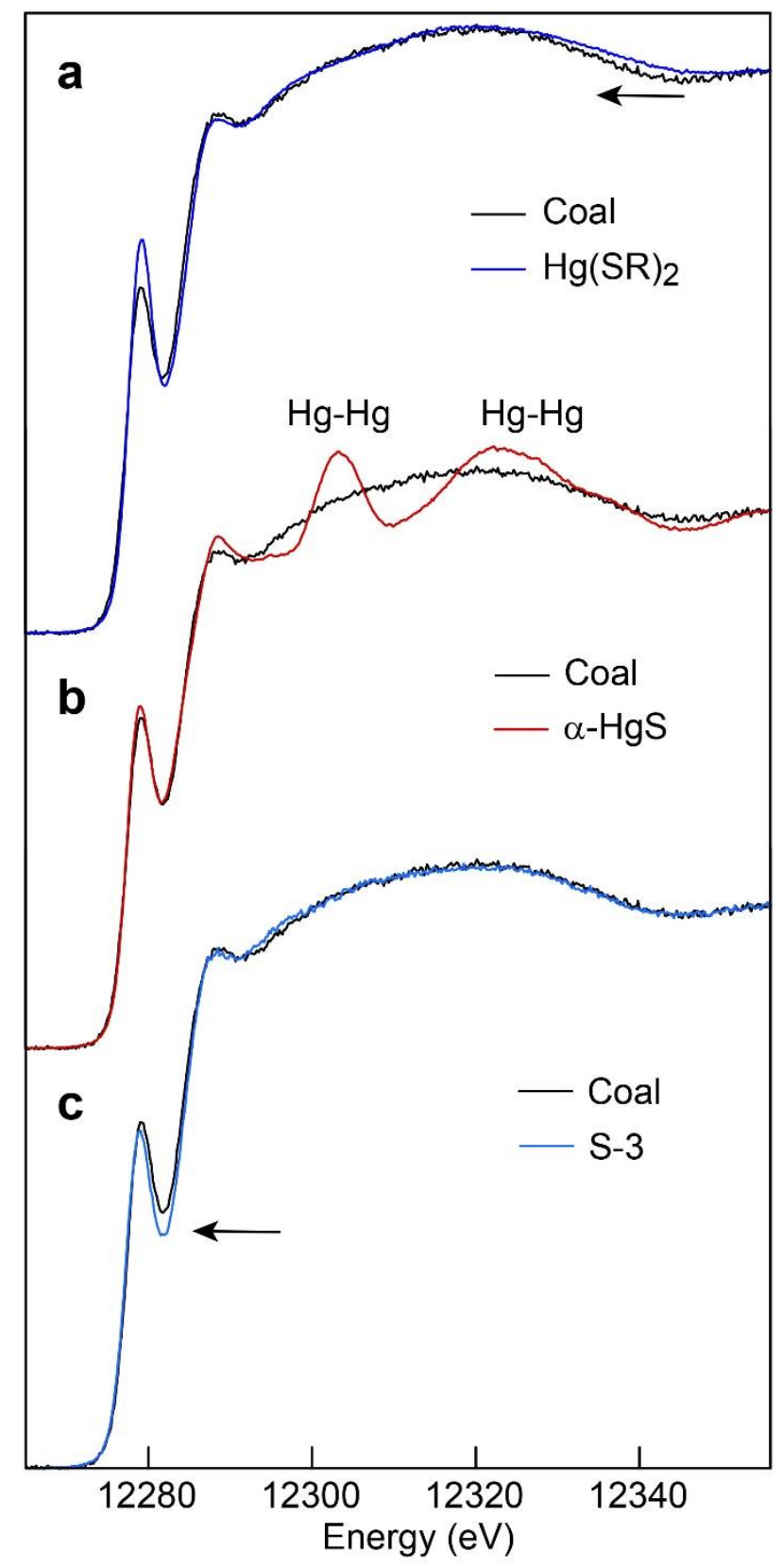

Figure 4 


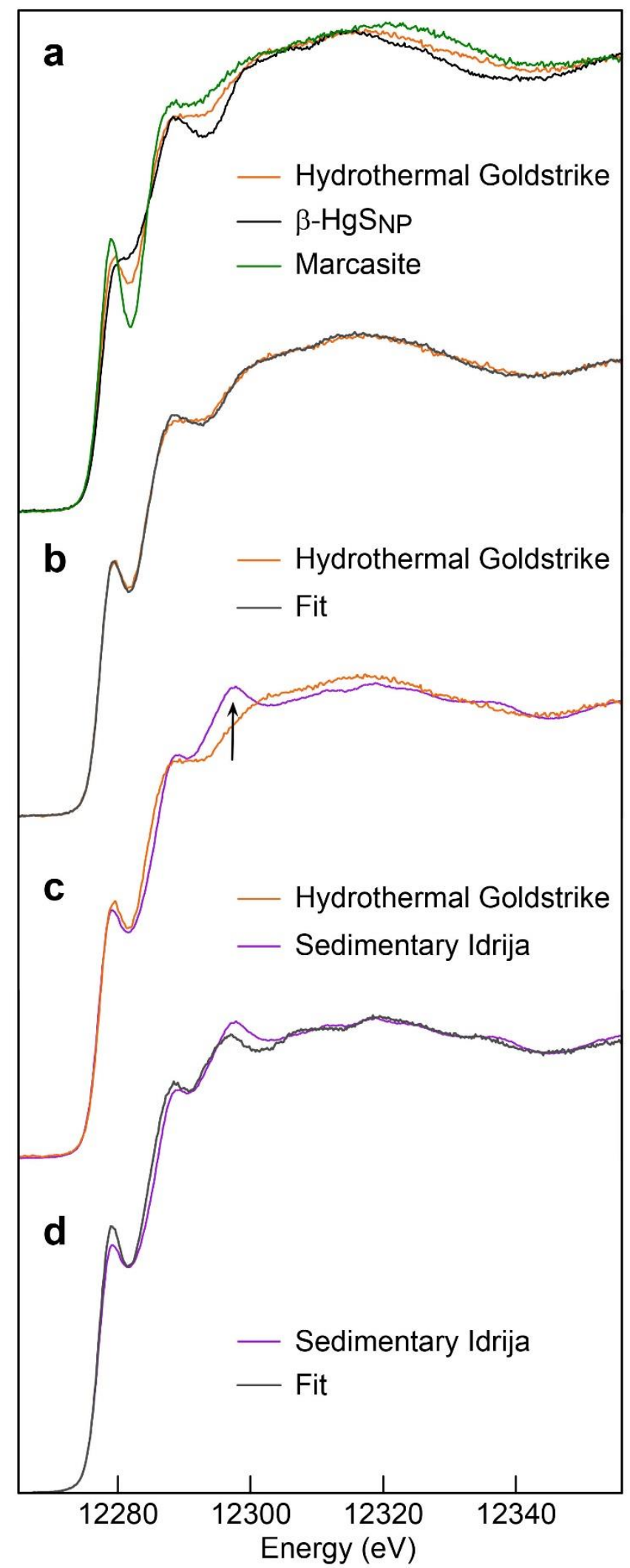

Figure 5 